\title{
Identificação de Pectobacterium carotovorum subsp. brasiliensis Através de PCR-RFLP do Gene recA
}

\author{
Samira O. M. El Tassa ${ }^{1}$ \& Valmir Duarte ${ }^{2}$ \\ ${ }^{1}$ Ministério da Agricultura, Pecuária e Abastecimento, Superintendência Federal de Agricultura, Pecuária e \\ Abastecimento no Rio Grande do Sul, Av. Loureiro da Silva, 515, CEP 90010-420, Porto Alegre, RS, fax: (51) 3284- \\ 9532, e-mail: samiracolodel@agricultura.gov.br; ${ }^{2}$ Departamento de Fitossanidade, Faculdade de Agronomia, UFRGS, \\ Cx. Postal 15100, CEP 90001-970, Porto Alegre, RS, fax: (51) 3316-6016, e-mail: valmir@ufrgs.br
}

(Aceito para publicação em 22/07/2005)

Autor para correspondência: Valmir Duarte

EL TASSA, S.O.M. \& DUARTE, V. Identificação de Pectobacterium carotovorum subsp. brasiliensis através de PCRRFLP do gene recA. Fitopatologia Brasileira 31:023-028. 2006.

\section{RESUMO}

Pectobacterium carotovorum subsp. brasiliensis foi proposta como o principal agente causal da canela preta da batata (Solanum tuberosum) no Brasil. Com o objetivo de identificar essa subespécie, oligonucleotídeos iniciadores foram selecionados a partir de regiões heterólogas do gene recA existentes entre P. carotovorum subsp. brasiliensis ATCC BAA41 e outras pectobactérias disponíveis no GenBank e $P$. carotovorum subsp. carotovorum BAB1. No entanto, os oligonucleotídeos iniciadores apresentaram baixa especificidade. O produto da PCR do gene recA, um fragmento de \pm 730 pb, de 38 estirpes de $P$. chrysanthemi e das diferentes subespécies de P. carotovorum, foi digerido com as endonucleases de restrição TasI e HhaI. Estas enzimas foram selecionadas com base na seqüência do gene recA das estirpes $P$. carotovorum subsp. brasiliensis ATCC BAA-416 (581 pb) e P. carotovorum subsp. carotovorum BAB1 (626 pb). A análise do PCRRFLP com as enzimas TasI e HhaI gerou sete e 12 padrões, respectivamente. A combinação dos resultados permitiu a separação em 13 grupos distintos e a discriminação de $P$. carotovorum subsp. brasiliensis.

Palavras-chave adicionais: pectobactérias, canela preta, podridão-mole, batata, Solanum tuberosum.

\begin{abstract}
Identification of Pectobacterium carotovorum subsp. brasiliensis through PCR-RFLP of the rec-A gene

Pectobacterium carotovorum subsp. brasiliensis has been proposed to be the major causal agent of blackleg of potato (Solanum tuberosum) in Brazil. In order to identify this subspecies, primers were selected from heterologous regions of recA genes present in P. carotovorum subsp. brasiliensis ATCC BAA-41, P. carotovorum subsp. carotovorum BAB1, and other DNA sequences of pectobacteria available in the GenBank. These primers, however, showed low specificity. The recA gene PCR product, a DNA fragment of \pm 730 bp, from 38 strains of $P$. chrysanthemi, subspecies of $P$. carotovorum, was digested with TasI and HhaI restriction enzymes. These enzymes were selected based on the sequences of recA gene from strains of $P$. carotovorum subsp. brasiliensis ATCC BAA-416 (581 pb) and P. carotovorum subsp. carotovorum BAB1 (626 pb). The restriction fragment length polymorphism (PCR-RFLP) analysis with TasI and HhaI enzymes generated seven and 12 patterns, respectively. Analysis of the combined results allowed for the separation of 13 distinct groups and differentiation of $P$. carotovorum subsp.brasiliensis.
\end{abstract}

Additional keywords: pectobacteria, blackleg of potato, potato, Solanum tuberosum.

\section{INTRODUÇÃO}

Pectobacterium carotovorum subsp. atrosepticum (van Hall) Hauben et al., P. carotovorum subsp. carotovorum (Jones) Hauben et al., P. chrysanthemi (Bulkholder et al.) Brenner et al. emend. Hauben et al. e, mais recentemente, $P$. carotovorum subsp. brasiliensis Duarte et al. (Duarte et al., 2004) são as bactérias responsáveis por causar podridão-mole em tubérculos e/ou canela-preta em plantas de batata (Solanum tuberosum L.) (Pérombelon \& Kelman, 1987; Duarte et al., 2004). Esta última subespécie foi proposta conforme estudos que mostraram que estirpes brasileiras, isoladas de lavouras do Rio Grande do Sul, inicialmente identificadas como P. carotovorum subsp. atrosepticum
(Oliveira et al., 2003), apresentaram perfis genéticos, bioquímicos, fisiológicos e sorológicos diferentes dos esperados para essa subespécie (Duarte et al., 2004). Levantamento posterior, em tubérculos-semente também produzidos nesse estado, mostrou a ausência de $P$. carotovorum subsp. atrosepticum e uma alta incidência de P. carotovorum subsp. brasiliensis (El Tassa \& Duarte, 2004).

A aparente ausência de $P$. carotovorum subsp. atrosepticum (El Tassa \& Duarte, 2004), principal agente causador de canela preta em outros países, e a presença de $P$. carotovorum subsp. brasiliensis em batata, faz com que as ferramentas para diagnóstico disponíveis no mercado, como anticorpos monoclonais (De Boer \& McNaughton, 1987) e oligonucleotídeos iniciadores específicos (De Boer \& Ward, 
1995; Bertheau et al., 1998) não possam ser utilizadas em programas de certificação no Brasil. Testes bioquímicos e fisiológicos demandam tempo, são trabalhosos e, além disso, a ocorrência de formas intermediárias dificulta a interpretação dos resultados, impossibilitando muitas vezes a identificação correta dessas bactérias (Stanguellini \& Meneley, 1975; Jabuonski et al., 1986; Pérombelon \& Van Der Wolf, 1998). Novas alternativas baseadas no sequenciamento de genomas bacterianos e no emprego de vários marcadores moleculares têm fornecido mais informações sobre a especificidade dos genomas. Assim como 16S e 23S rDNA, o gene recA, que codifica a enzima recombinase $\mathrm{A}$, pode servir como marcador para a identificação de patógenos bacterianos (Ludwing \& Schleifer, 1999). RecA é uma proteína multifuncional envolvida na recombinação homóloga, reparo do DNA e na resposta SOS (Eisen, 1995). Comparações da seqüência da proteína RecA e do gene recA têm sido usadas para especular o relacionamento filogenético entre gêneros e espécies (Lloyd \& Sharp, 1993; Eisen, 1995; Karlin et al., 1995). Caracterização genotípica, baseada na análise de PCR-RFLP do gene recA, foi feita com membros do gênero Erwinia/ Pectobacterium (Waleron et al., 2002). Essa análise resultou na identificação de espécies e subespécies, bem como de estirpes de $P$. carotovorum subsp. carotovorum e $P$. chrysanthemi.

Dessa forma, este trabalho teve por objetivo identificar $P$. carotovorum subsp. brasiliensis através da análise da seqüência e PCR-RFLP do gene recA.

\section{MATERIAL E MÉTODOS}

\section{Estirpes} Tabela 1.

As estirpes usadas neste estudo estão listadas na

\section{Extração de DNA}

Células bacterianas, cultivadas em meio de cultura Nutriente Agar, com 24-48 h, foram transferidas para 250 $\mu \mathrm{l}$ de tampão de extração (100mM tris- $\mathrm{HCl}$ pH 8,0; 25 mM EDTA; 1\% SDS e $5 \mu$ g de proteinase K), com o auxílio de um palito de dente e incubadas por $3 \mathrm{~h}$ a $56{ }^{\circ} \mathrm{C}$ em banhomaria. Posteriormente, adicionou-se $250 \mu \mathrm{l}$ de acetato de amônio 7,5 M e procedeu-se a centrifugação a 14.000 g por 10 min. O sobrenadante foi transferido para outro tubo, adicionado igual volume de isopropanol e incubado durante a noite a $-20{ }^{\circ} \mathrm{C}$. O precipitado obtido após centrifugação por 25 min a $14.000 \mathrm{~g}$ a $4{ }^{\circ} \mathrm{C}$, foi lavado com etanol $70 \%$, seco a temperatura ambiente, dissolvido em $50 \mu \mathrm{l}$ de água ultra pura e armazenado a $-20{ }^{\circ} \mathrm{C}$ (De Boer \& Ward, 1995).

\section{PCR e sequenciamento}

O DNA extraído dos isolados foi submetido a PCR, utilizando os seguintes oligonucleotídeos iniciadores $\left(5^{\prime} \rightarrow 3^{\prime}\right)$ :

TABELA 1 - Estirpes de Pectobacterium sp. usadas neste estudo. Porto Alegre, 2004

\begin{tabular}{|c|c|c|c|}
\hline Identificação/n ${ }^{\circ}$ de estirpes & Hospedeiro & Origem & Fonte \\
\hline $\begin{array}{l}\text { Pectobacterium carotovorum } \\
\text { IAC } 2, \text { IAC } 3, \text { BAB } 5\end{array}$ & Batata (Solanum tuberosum L.) & Brasil & S. O. M. El Tassa/UFRGS \\
\hline $\begin{array}{l}\text { P. carotovorum subsp. atrosepticum } \\
31\end{array}$ & Batata & & CFIA,CA \\
\hline $\begin{array}{l}\text { P. carotovorum subsp. betavasculorum } \\
\text { LMG2464, } \\
\text { IBSBF787 (ATCC43762) }\end{array}$ & $\begin{array}{l}\text { Beterraba açucareira } \\
\text { (Beta vulgaris L.) }\end{array}$ & $\begin{array}{l}\text { EUA } \\
\text { EUA }\end{array}$ & $\begin{array}{l}\text { CFIA,CA } \\
\text { Instituto Bioló gico, } \mathrm{BR}\end{array}$ \\
\hline $\begin{array}{l}\text { P. carotovorum subsp. brasiliensis }(20) \\
\text { ATCC BAA-416, ATCC BAA-417 }{ }^{\mathrm{T}} \text {, ATCC } \\
\text { BAA-418, ATCC BAA-419 } \\
\text { MB1, MB8, BAPB6, BAPB8, EPB11, } \\
\text { BIPB15, APB14, CBC2, CMAC19, PMAR2, } \\
\text { PMAB3, PMAB11, PAB10, IEC5, CBC1 } 285\end{array}$ & Batata & Brasil & $\begin{array}{c}\text { V. Duarte/UFRGS } \\
\text { S. O. M. El Tassa/ UFRGS }\end{array}$ \\
\hline $\begin{array}{l}\text { P. carotovorum subsp. carotovorum (6) } \\
\text { IBSBF } 1442 \\
\text { BAB1, BAB3, CBC11, PPR5, PMAR14 }\end{array}$ & $\begin{array}{l}\text { Dianthus caryophylus } \mathrm{L} . \\
\text { Batata }\end{array}$ & Argentina & $\begin{array}{r}\text { C. C. Rommel/UFRGS } \\
\text { Instituto Bioló gico, BR } \\
\text { S. O. M. El Tassa/ UFRGS }\end{array}$ \\
\hline $\begin{array}{l}\text { P. carotovorum subsp. odoriferum (1) } \\
\text { CFBP1645 }\end{array}$ & Chicória (Chicorium endivia L.) & França & CFIA, CA \\
\hline $\begin{array}{l}\text { P. carotovorum subsp. wasabiae (4) } \\
\text { SR91 }{ }^{\mathrm{T}} \text {, SR92, SR93, SR94 }\end{array}$ & Horseradish (Eutrema wasabi Maxim.) & Japão & CFIA, CA \\
\hline $\begin{array}{l}\text { P. chrysanthemi (1) } \\
\text { IBSBF1468 }\end{array}$ & Cebola (Allium cepae L.) & Brasil & Instituto Biológico, $\mathrm{BR}$ \\
\hline
\end{tabular}


(GGT AAA GGG TCT ATC ATG CG) / (CCT TCA CCA TAC ATA ATT TGG A) (Waleron et al., 2002) que produzem um fragmento de $730 \mathrm{pb}$ do gene recA. As reações foram feitas em um volume final de $50 \mu \mathrm{l}$, onde foi usado $1 \mu \mathrm{M}$ de cada oligonucleotídeo iniciador; tampão de reação (10 mM Tris $\mathrm{pH}$ 8,3; $50 \mathrm{mM} \mathrm{KCl);} \mathrm{2,5} \mathrm{mM} \mathrm{de} \mathrm{MgCl}_{2} ; 0,25 \mathrm{mM}$ de cada dNTP (Invitrogen); 1,0 unidade de Taq DNA polimerase (Invitrogen) e cerca de 100 ng de DNA (Waleron et al., 2002). As amplificações foram conduzidas em termociclador MJ Research (PTC-100), nas seguintes condições: $95^{\circ} \mathrm{C} / 3 \mathrm{~min}$, $\left(94^{\circ} \mathrm{C} / 1 \mathrm{~min}, 47^{\circ} \mathrm{C} / 1 \mathrm{~min}, 7{ }^{\circ} \mathrm{C} / 2 \mathrm{~min}\right.$ ) $32 \mathrm{X}, 72^{\circ} \mathrm{C} / 5 \mathrm{~min}$. Os produtos das amplificações foram separados por eletroforese juntamente com marcador de peso molecular 100 $\mathrm{pb}$ (Promega), a 4V/cm por $2 \mathrm{~h}$, em gel de agarose 1\%, corado com brometo de etídeo, visualizado sob luz ultra-violeta e fotografado através de sistema de análise de gel computadorizado (Kodak Digital Science 1D). Posteriormente, $45 \mu$ do produto da reação de duas estirpes (P. carotovorum subsp. brasiliensis ATCC BAA-416 e $P$. carotovorum subsp. carotovorum BAB1) foram encaminhados para sequenciamento no Core Molecular Biology Facility York University (North York, Ontário, Canadá).

\section{Seleção de oligonucleotídeos iniciadores e PCR}

As seqüências obtidas foram avaliadas quanto à homologia entre si e com outras seqüências disponíveis na base de dados do GenBank usando o programa BLASTN. Oligonucleotídeos iniciadores foram selecionados a partir de regiões heterólogas da sequiência de DNA, entre $P$. carotovorum subsp. brasiliensis e as demais estirpes.

A PCR usando estes oligonucleotídeos iniciadores teve as mesmas condições descritas anteriormente. No entanto, visando melhorar a especificidade da reação, diferentes temperaturas de anelamento $\left(47-68^{\circ} \mathrm{C}\right)$ e número de ciclos (25 e 30) foram testados.

\section{PCR - RFLP do gene recA}

A PCR foi feita como descrita anteriormente. O DNA presente na reação $(40 \mu \mathrm{l})$ foi precipitado com $4,5 \mu \mathrm{l}$ de acetato de amônio $3 \mathrm{M}$ e $44,5 \mu \mathrm{l}$ de isopropanol a $-20{ }^{\circ} \mathrm{C}$ durante a noite. $\mathrm{O}$ precipitado foi centrifugado a $17.000 \mathrm{~g}$ por $10 \mathrm{~min}$, lavado com $500 \mu \mathrm{l}$ de etanol $70 \%$, centrifugado novamente na mesma condição anterior, seco a temperatura ambiente e ressuspendido em $10 \mu \mathrm{l}$ de água ultrapura. O DNA foi digerido com duas endonucleases de restrição [HhaI (Invitrogen) e TasI (Fermentas)], as quais foram selecionadas com base na seqüência de nucleotídeos do gene recA das estirpes $P$. carotovorum subsp. brasiliensis ATCC BAA-416 e $P$. carotovorum subsp. carotovorum BAB1, usando o programa Webcutter (Heiman, 2003). A digestão foi feita durante a noite (aproximadamente $12 \mathrm{~h}$ ) num volume final de $10 \mu \mathrm{l}$ contendo 2,5 $\mathrm{U}$ de cada endonuclease usando o tampão e temperatura $\left[37^{\circ} \mathrm{C}(\right.$ HhaI $)$ e $65^{\circ} \mathrm{C}$ (TasI)] recomendados pelo fabricante. Os fragmentos foram separados em gel de agarose $2,5 \%$, juntamente com marcador de peso molecular
$50 \mathrm{pb}$ (Amersham Biosciences), através de eletroforese de 4 V/cm por $8 \mathrm{~h}$, corado com brometo de etídeo, visualizado sob luz ultra-violeta e fotografado através do sistema de análise de gel computadorizado (Kodak Digital Science 1D). Os padrões de PCR-RFLP, para cada enzima, foram baseados no número de bandas e sua posição. Os grupos de RFLP foram formados pela análise combinada dos padrões obtidos.

\section{RESULTADOS}

\section{Sequenciamento do gene recA}

A PCR com os oligonucleotídeos iniciadores do gene recA produziu um fragmento de aproximadamente $730 \mathrm{pb}$ para as estirpes analisadas, sendo que o seqüenciamento dos fragmentos das estirpes $P$. carotovorum subsp. brasiliensis ATCC BAA-416 e P. carotovorum subsp. carotovorum BAB1, resultou em seqüências de 581 e 626 pb, respectivamente. A homologia entre as duas seqüências foi de $90 \%$. No entanto, a homologia entre a seqüência do gene recA da estirpe P. carotovorum subsp. brasiliensis ATCC BAA-416 com as outras sequiências do mesmo gene disponíveis no GenBank, variou de 90 a 99\% com as estirpes das subespécies de $P$. carotovorum. A maior homologia foi verificada com as estirpes de $P$. carotovorum subsp. carotovorum.

\section{Seleção de oligonucleotídeos iniciadores e PCR}

Oligonucleotídeos iniciadores, recAF e recAR, foram selecionados a partir de regiões da seqüência de $P$. carotovorum subsp. brasiliensis ATCC BAA-416 de baixa homologia quando comparada com as outras seqüências disponíveis no GenBank e com P. carotovorum subsp. carotovorum BAB1. Um fragmento, de tamanho esperado, de $429 \mathrm{pb}$ foi amplificado do DNA das estirpes de $P$. carotovorum subsp. brasiliensis. No entanto, quando as temperaturas de anelamento variaram entre $47-60{ }^{\circ} \mathrm{C}$, algumas estirpes de $P$. carotovorum subsp. carotovorum tiveram o mesmo fragmento amplificado. Em temperaturas superiores a $60^{\circ} \mathrm{C}$, estas estirpes não tiveram o fragmento amplificado, juntamente com algumas P. carotovorum subsp. brasiliensis (Figura 1).

\section{PCR-RFLP do gene recA}

A menor diferenciação dos padrões de RFLP foi observado com TasI, com somente sete padrões com as estirpes testadas (Tabela 2). A maior diferenciação foi obtida com a enzima HhaI, com 12 padrões. O resultado da análise dos padrões (Figura. 2) combinados de PCR-RFLP com o produto do gene recA, usando as enzimas HhaI e TasI, revelarou a presença de 13 diferentes grupos de RFLP (Tabela 2). Estes grupos foram consistentemente diferentes e característicos para as espécies e subespécies testadas, com exceção da estirpe P. carotovorum subsp. carotovorum PPR5 que está presente no mesmo grupo das estirpes de $P$. carotovorum subsp. brasiliensis. A maior diversidade do gene foi observada entre seis estirpes de $P$. carotovorum subsp. carotovorum, com cinco grupos de RFLP. Por outro lado, as 


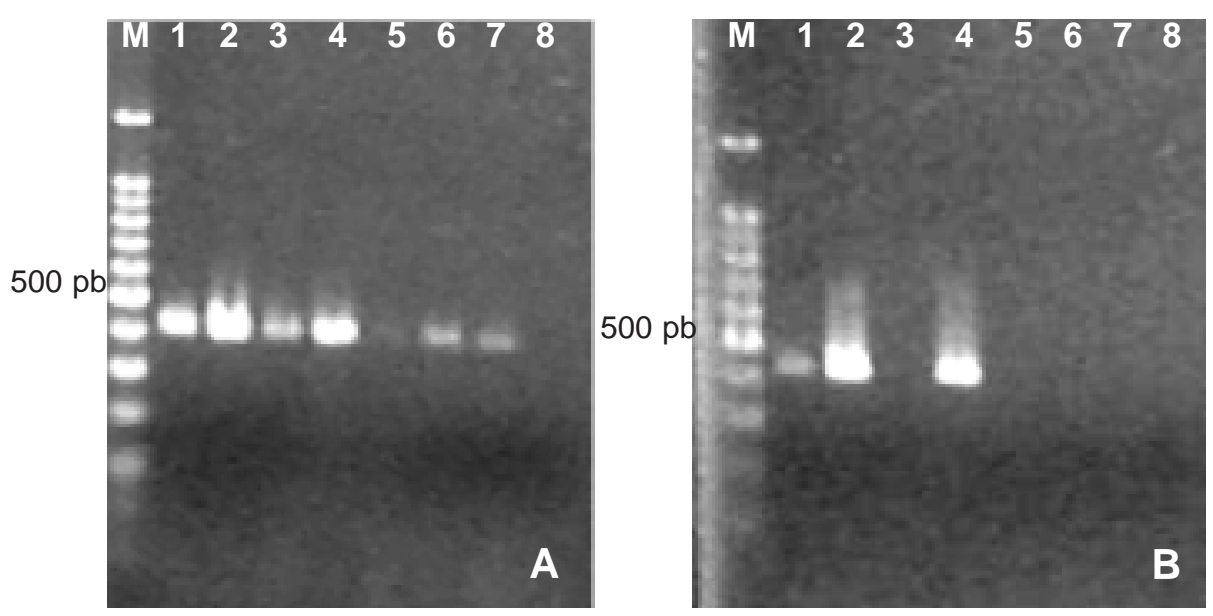

FIG. 1 - Produtos da PCR usando os oligonucleotídeos iniciadores recAF e recAR com duas temperaturas de anelamento A, $60{ }^{\circ} \mathrm{C}$; B, $65^{\circ} \mathrm{C}$. M, marcador de peso molecular $100 \mathrm{pb}$; 1, Pectobacterium carotovorum subsp. brasiliensis ATCC BAA-416; 2, P. carotovorum subsp. brasiliensis ATCC BAA-417T; 3, P. carotovorum subsp. brasiliensis ATCC BAA-417; 4, P. carotovorum subsp. brasiliensis ATCC BAA-418; 5, P. carotovorum subsp. brasiliensis 285; 6, P. carotovorum subsp. carotovorum PLT1; 7, P. carotovorum subsp. carotovorum IBSBF 1442; 8, negativo (sem DNA).

TABELA 2 - Grupos de RFLP obtidos com base na análise de restrição do fragmento do gene recA com duas endonucleases de restrição. Porto Alegre, 2004

\begin{tabular}{|c|c|c|c|c|}
\hline \multirow{2}{*}{$\begin{array}{l}\text { Grupos de } \\
\text { RFLP }^{1}\end{array}$} & \multicolumn{2}{|c|}{$\begin{array}{l}\text { Padrão de PCR -RFLP para } \\
\text { endonucleases de restrição }\end{array}$} & \multirow[t]{2}{*}{ Estirpes $^{2}$} & \multirow{2}{*}{$\begin{array}{r}\mathbf{N}^{0} \text { de } \\
\text { estirpes }\end{array}$} \\
\hline & Hha I & Tas I & & \\
\hline \multirow[t]{2}{*}{1} & 1 & 1 & Pcbr ATCC BAA 416, ATCC BAA-417T, ATCC BAA-419 & 9 \\
\hline & & & 419, pmab3, pmab11, iec5, mb1, mb8, apb14 & \\
\hline \multirow[t]{2}{*}{2} & 2 & 1 & $\begin{array}{l}\text { Pcbr ATCC BAA -418, cbc2, pmar2, pab10, cbc1, bapb6, } \\
\text { bapb8, epb11, cmac19 }\end{array}$ & 9 \\
\hline & & & Pcc ppr5 & 1 \\
\hline 3 & 1 & 2 & Pcbr bipb15 & 1 \\
\hline 4 & 3 & 1 & Pcc IBSBF1442 & 1 \\
\hline 5 & 5 & 1 & Pcc cbc11 & 1 \\
\hline 6 & 6 & 1 & Pcc pmar14 & 1 \\
\hline \multirow[t]{2}{*}{7} & 4 & 3 & Pcc bab1, bab3 & 2 \\
\hline & & & Pc iac2, iac3, bab5 & 3 \\
\hline 8 & 7 & 4 & Pcb IBSBF787 (ATCC43762 $)$, LMG2464T & 2 \\
\hline 9 & 8 & 5 & Pcw SR94, SR93, SR92 & 3 \\
\hline 10 & 9 & 5 & Pcw SR91T & 1 \\
\hline 11 & 10 & 2 & Pco CFBP1645 & 1 \\
\hline 12 & 11 & 6 & Pch IBSBF1468 & 1 \\
\hline 13 & 12 & 7 & Pca 31 & 1 \\
\hline
\end{tabular}

${ }^{1}$ Número dos grupos de RFLP baseados nos padrões combinados de PCR-RFLP com as endonucleases de restrição HhaI e TasI.

${ }^{2}$ Pcbr, Pectobacterium carotovorum subsp. brasiliensis; Pcc, P. carotovorum subsp. carotovorum; Pc, P. carotovorum; Pcb, P. carotovorum subsp. betavasculorum; Pcw, P. carotovorum subsp. wasabiae; Pco, P. carotovorum subsp. odoriferum; Pca, P. carotovorum subsp. atrosepticum; Pch P. chrysanthemi.

19 estirpes de $P$. carotovorum subsp. brasiliensis testadas estão distribuídas em três grupos. Três estirpes de $P$. carotovorum, caracterizadas pela ausência de crescimento a $37^{\circ} \mathrm{C}$, possuem o mesmo padrão de algumas estirpes de $P$. carotovorum subsp. carotovorum, ficando incluídas no mesmo grupo de RFLP. Estas estirpes já haviam sido identificadas pelo sistema Biolog (Hayward, EUA) como $P$. carotovorum subsp. carotovorum (El Tassa \& Duarte, 2004) e a análise de rep-PCR mostrou que elas estão presentes no mesmo grupo de $P$. carotovorum subsp. carotovorum (El Tassa \& Duarte, 2003).

\section{DISCUSSÃO}

Segundo Duarte et al. (2004), análises sorológicas e de composição de ácidos graxos confirmaram que estirpes 

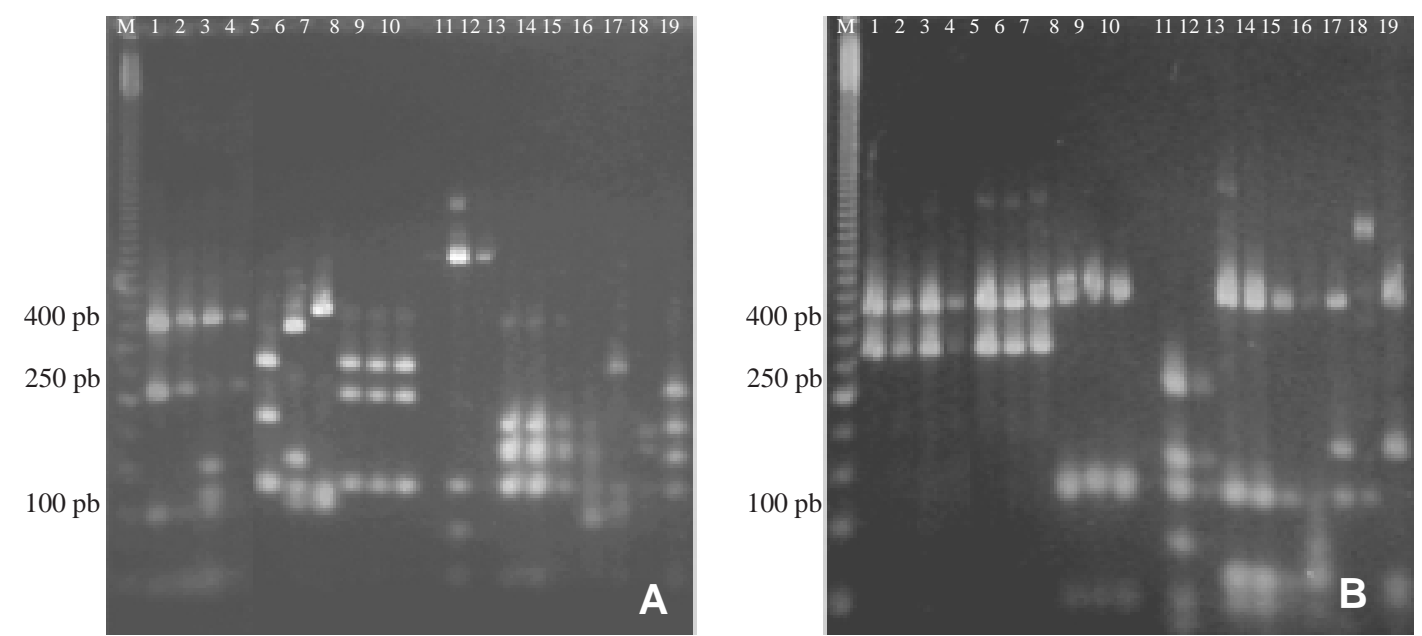

FIG. 2 - Padrões de PCR-RFLP do gene recA com as edonucleases de restrição HhaI (A) e TasI (B). M, marcador de peso molecular 50 pb; 1, Pectobacterium carotovorum subsp. brasiliensis ATCC BAA-416; 2, P. carotovorum subsp. brasiliensis ATCC BAA-417T; 3, P. carotovorum subsp. brasiliensis ATCC BAA-417; 4, P. carotovorum subsp. brasiliensis ATCC BAA-418; 5, P. carotovorum subsp. carotovorum CBC11; 6, P. carotovorum subsp. carotovorum PPR5; 7, P. carotovorum subsp. carotovorum PMAR14; 8, P. carotovorum IAC2; 9, P. carotovorum IAC3; 10, P. carotovorum BAB5; 11, P. carotovorum subsp. betavasculorum IBSBF787; 12, P. carotovorum subsp. betavasculorum LMG2464 ; 13 , P. carotovorum subsp. wasabiae SR94; 14 , P. carotovorum subsp. wasabiae SR93; 15, P. carotovorum subsp. wasabiae SR92; 16, P. carotovorum subsp. wasabiae SR91 ${ }^{\mathrm{T}}$; 17 , P. carotovorum subsp. odiriferum CFBP1645; 18, P. chrysanthemi IBSBF1468; 19, P. carotovorum subsp. atrosepticum 31.

de $P$. carotovorum subsp. brasiliensis diferem de $P$. carotovorum subsp. atrosepticum. O sítio de restrição da endonuclease SexAI na região IGS de $P$. carotovorum subsp. brasiliensis, aparentemente ausente nas outras subespécies e espécies de pectobactérias, foi usado para desenhar um oligonucleotídeo iniciador específico para $P$. carotovorum subsp. brasiliensis (Duarte et al., 2004). Mas quando este oligonucleotídeo foi usado na PCR para identificação de um número maior de estirpes de pectobactérias em batata, algumas $P$. carotovorum subsp. carotovorum apresentaram um fragmento do mesmo tamanho (El Tassa \& Duarte, 2004). Isto sugere que estas estirpes podem apresentar o sítio de restrição da enzima SexAI na mesma posição que $P$. carotovorum subsp. brasiliensis.

Dessa forma, um dos objetivos do presente trabalho foi selecionar oligonucleotídeos iniciadores específicos para $P$. carotovorum subsp. brasiliensis, que pudessem ser utilizados como ferramenta para sua detecção em trabalhos epidemiológicos e de controle. No entanto, o gene escolhido como alvo, recA, não se mostrou adequado para esta proposta. A falta de especificidade dos oligonucleotídeos iniciadores selecionados pode ser explicada pelo uso da endonuclease de restrição HhaI. O oligonucleotídeo iniciador recAF foi selecionado a partir de uma região que continha o sítio de restrição para essa enzima em outras estirpes de pectobactérias e não para $P$. carotovorum subsp. brasiliensis ATCC BAA-416. No entanto, a análise de RFLP do gene recA revelou que algumas estirpes de $P$. carotovorum subsp. brasiliensis (ATCC BAA-418, cbc2, pmar2, pab10, cbc1, bapb6, bapb8, epb11, cmac19) contém o sítio de restrição para a enzima HhaI na mesma posição. Isto explica a ausência de amplificação com temperaturas de anelamento mais altas, com algumas estirpes de $P$. carotovorum subsp. brasiliensis. Assim, estes oligonucleotídeos iniciadores não podem ser usados para detecção de $P$. carotovorum subsp. brasiliensis.

Por outro lado, PCR-RFLP do gene recA, com as endonucleases HhaI e TasI, evidenciou a formação de grupos distintos entre as subespécies analisadas, principalmente para P. carotovorum subsp. brasiliensis, apesar de uma estirpe de $P$. carotovorum subsp. carotovorum estar presente no mesmo grupo. Estes resultados corroboram os obtidos anteriormente com rep-PCR (El Tassa \& Duarte, 2003) onde as estirpes de $P$. carotovorum subsp. brasiliensis formaram um grupo homogêneo e separado das demais subespécies. Da mesma forma, evidencia a heterogeneidade de estirpes de $P$. carotovorum subsp. carotovorum. No entanto, o uso de outras enzimas de restrição e a análise combinada dos padrões de PCR-RFLP, poderão dar maior evidência da distinção entre as espécies e subespécies de pectobactérias.

A caracterização genotípica, realizada por Waleron et al. (2002), de estirpes do gênero Erwinia/Pectobacterium, através de PCR-RFLP do gene recA, identificou 57 grupos de RFLP, sendo 42 dentro do gênero Pectobacterium. Assim como no presente trabalho, o maior número de grupos de RFLP foi obtido com P. carotovorum subsp. carotovorum. Da mesma forma, Seo et al. (2002) identificaram dez grupos de RFLP, do gene recA, entre 92 estirpes de P. carotovorum subsp. carotovorum isoladas de diferentes hospedeiros. Um 
alto nível de variabilidade nesta subespécie já foi observado em estudos sorológicos (De Boer \& McNaughton, 1987) e em análises de RFLP de seqüências de genes de enzimas pectolíticas (Darrasse et al., 1994). Em contraste, neste trabalho as 19 estirpes de $P$. carotovorum subsp. brasiliensis estão distribuídas em apenas três grupos de RFLP. A baixa variabilidade nesta subespécie também tem sido observada com análise de rep-PCR (El Tassa \& Duarte, 2003).

O conhecimento da diversidade é um importante prérequisito para o desenvolvimento de métodos para identificação e detecção dessas fitobactérias, bem como para classificação taxonômica, estudos epidemiológicos e desenvolvimento de estratégias para o controle da doença, principalmente no que diz respeito à seleção de genótipos e desenvolvimento de variedades resistentes em programas de melhoramento. Isto é particularmente importante quando diferentes espécies e subespécies, bastante relacionadas, causam doença no mesmo hospedeiro, como é o caso das pectobactérias em batata.

Dessa forma, PCR-RFLP do gene recA pode ser usado para a identificação de $P$. carotovorum subsp. brasiliensis, bem como para estudar a variabilidade de estirpes de pectobactérias.

\section{REFERÊNCIAS BIBLIOGRÁFICAS}

BERTHEAU, Y., FRÉCHON,N., D., TOTH, I.K. \& HYMAN,L.J. DNA amplification by polymerase chain reaction (PCR). In: Pérombelon, M. C. M. \& Van Der Wolf, J. M. (Eds.) Methods for detection and quantification of Erwinia carotovora subsp. atroseptica potatoes: Laboratory Manual. Dundee. Scottish Crop Research Institute. 1998. pp.38-48.

DARRASSE, A., PRIOU, S., KOTOUJANSKY, A. \& BERTHEAU, Y. PCR and restriction fragment length polymorphism of a pel gene as a tool to identify Erwinia carotovora in relation to potato diseases. Applied and Environmental Microbiology 60:1437-1443. 1994.

DE BOER, S.H. \& McNAUGHTON, M.E. Monoclonal antibodies to the lipopolysaccharide of Erwinia carotovora subsp. atroseptica serogroup I. Phytopathology 77:828-832. 1987.

DE BOER, S.H. \& WARD, L.J. PCR detection of Erwinia carotovora subsp. atroseptica associated with potato tissue. Phytopathology 85:854-858. 1995.

DUARTE, V., DE BOER, S.H., WARD, L.J. \& DE OLIVEIRA, A.M.R. Characterization of atypical Erwinia carotovora strains causing blackleg of potato in Brazil. Journal of Applied Microbiology 96:535-545. 2004.

EISEN, J.A. The RecA protein as a model molecule for molecular systematic studies of bacteria: Comparison of trees of RecAs and 16S rRNAs from the same species. Journal of Molecular Evolution 41:1105-1123. 1995.

EL TASSA, S.O.M. \& DUARTE, V. Caracterização molecular de pectobactérias por ERIC-PCR, BOX-PCR e RAPD. Fitopatologia Brasileira 28:S239. 2003. (Suplemento)

EL TASSA, S.O.M. \& DUARTE, V. Ocorrência de pectobactérias em tubérculos de batata-semente no Rio Grande do Sul. Fitopatologia Brasileira. 29:620-625. 2004.

HEIMAN, M. Webcutter, versão 2.0. Texas: First Market Research, 1997. Disponível em: http://www.firstmarket.com/cutter/ cut2.html. Acesso em: 30 nov. 2003.

JABUONSKI, R.E., TAKATSU, A. \& REIFSCHNEIDER, F.J.B. Levantamento e identificação de espécies de Erwinia de diferentes plantas hospedeiras e regiões do Brasil. Fitopatologia Brasileira 11:185-195. 1986.

KARLIN, S., WEINSTOCK, G.M. \& BRENDEL, V. Bacterial classification derived from RecA protein sequence comparisons. Journal of Bacteriology 177:6881-6893. 1995.

LLOYD, A.T. \& SHARP, P.M. Evolution of the recA gene and molecular phylogeny of bacteria. Journal of Molecular Evolution 37:399-407. 1993.

LUDWING, W. \& SCHLEIFER, K.H. Phylogeny of bacteria beyond the 16 rRNA standard. ASM News 65:752-757. 1999.

OLIVEIRA, A. M. R., DUARTE, V., SILVEIRA, J.R.P. \& MORAES, M.G. Incidence of pectolytic erwinias associated with blackleg of potato in Rio Grande do Sul. Fitopatologia Brasileira 28:49-53. 2003.

PÉROMBELON, M.C.M. \& KELMAN, A. Blackleg and other potato diseases caused by soft rot Erwinias: Proposal for revision of terminology. Plant Disease 71:283-285. 1987.

PÉROMBELON, M.C.M. \& KELMAN, A. Ecology of the soft rot erwinias. Annual Review of Phytopathology 18:361-387. 1980.

PÉROMBELON, M.C.M. \& VAN DER WOLF, J.M. (Eds.). Methods for detection and quantification of Erwinia carotovora subsp. atroseptica in potatoes. Laboratory Manual. Dundee. Scottish Crop Res. 1998.

SEO, S.T., FURUYA, N., TAKESHITA, M. \& TAKANAMI, Y. Genotyping of Erwinia carotovora subsp. carotovora strains from Asia based on recA gene restriction fragment length polymorphisms. Journal of the Faculty of Agriculture 47:7-12. 2002.

STANGHELLINI, M.E. \& MENELEY, J.C. Identification of soft rot Erwinia associated with blackleg in Arizona. Phytopathology 65:86-87. 1975.

WALERON, M., WALERON, K., PODHAJSKA, A.J. \& LOJKOWSKA, E. Genotyping of bacteria belonging to the former Erwinia genus by PCR-RFLP analysis of a recA gene fragment. Microbiology 148:583-595. 2002. 